\title{
Uloga životnih vrijednosti u objašnjenju stavova prema razvodu braka - međugeneracijska i unutarobiteljska perspektiva
}

\section{Ina Reić Ercegovac}

Filozofski fakultet, Odsjek za pedagogiju, Sveučilište u Splitu, Hrvatska e-mail: inareic@ffst.hr

\section{Morana Koludrović \\ Filozofski fakultet, Odsjek za pedagogiju, Sveučilište u Splitu, Hrvatska e-mail:morana@ffst.hr}

SAŽETAK Hrvatsko društvo karakteriziraju promjene koje su se odrazile na percepciju i praksu bračnih i obiteljskih odnosa u smislu napuštanja patrijarhalnoga modela braka i obitelji (Nikodem, 2010.), što se dijelom ogleda i u rastućoj stopi razvoda braka. Ipak, istraživanja pokazuju da obitelj i dalje predstavlja najvažniju vrijednost u europskom i hrvatskom kontekstu, te je najvažniji socijalizacijski čimbenik u formiranju vrijednosnoga sustava pojedinca. U kontekstu unutarobiteljskoga modela prijenosa vrijednosti (Goodnow, 1992.), za očekivati je da na razini obitelji postoji sličnost u vrijednosnim prioritetima i stavovima. Pa ipak, u nekim istraživanjima nije potvrđena ova pretpostavka (Josefowicz i sur., 1994.). Stoga se ovim istraživanjem željelo ispitati postoje li, s jedne strane, generacijske razlike u vrijednostima i stavovima prema razvodu, te, s druge strane, postoji li unutarobiteljska kongruentnost s obzirom na iste varijable. Budući da je vrijednosti moguće razmatrati i kao uzroke stavova te ponašanja pojedinaca, jedan od ciljeva ovoga istraživanja bio je ispitati determiniraju li životne vrijednosti stavove prema razvodu braka.

U istraživanju je sudjelovalo 306 sudionica, odnosno 153 para majki i njihovih kćeri starije adolescentne i postadolescentne dobi. Primijenjena je skraćena verzija inventara Životnih vrijednosti (Crace i Brown, 1996.), te skala stavova prema razvodu braka (Kinnard i Gerard, 1986.).

Rezultati istraživanja su ukazali na značajno pozitivniji stav prema razvodu braka te na značajno veće vrednovanje intime kao životne vrijednosti u skupini kćeri u odnosu na skupinu majki. Na unutarobiteljskoj razini potvrđena je značajna povezanost u vrijednosnim prioritetima i stavu prema razvodu braka. U obje skupine sudionica duhovnost kao životna vrijednost pokazala se prediktivnom za stav prema razvodu, dok ostale vrijednosti uglavnom nisu relevantne za stav prema razvodu braka.

Ključne riječi: životne vrijednosti, stavovi prema razvodu braka, generacijske razlike, unutarobiteljska povezanost. 


\section{Uvod}

\section{1. Životne vrijednosti}

Brojni su pristupi definiranja i istraživanja vrijednosti, a za potrebe ovoga rada vrijednosti će se razmatrati u kontekstu Brownove holističke teorije izbora životnih uloga temeljenih na vrijednostima (Brown, 1996.). Prema Brownu (1996.) vrijednosti služe kao standardi pomoću kojih vrednujemo svoje aktivnosti i ponašanja drugih. One usmjeravaju pojedinca u snalaženju na osobnoj, grupnoj i globalnoj razini, a imaju i samoaktualizirajuću funkciju. Vrijednosti su organizirane u vrijednosni sustav koji predstavlja hijerarhiju vrijednosti s obzirom na njihovu relativnu važnost u životu pojedinca. Brown (1996.) navodi da su u tako hijerarhijski organiziranom sustavu vrijednosti prioritetne one koje su najvažnije odrednice odabira životnih uloga, a salijentnost životnih uloga odraz je vrijednosnoga sustava pojedinca (Šverko, Babarović i Šverko, 2007.).

Brojni su osobni i društveni čimbenici koji sudjeluju u stvaranju vrijednosnoga sustava pojedinca. Pri tome se posebno ističe obitelj koja, s jedne strane, predstavlja najvažniju društvenu vrijednost u europskom i hrvatskom kontekstu (Nacionalna obiteljska politika, 2003.), a, s druge strane, predstavlja najvažniji socijalizacijski čimbenik u izgradnji pojedinčevoga vrijednosnog sustava. Obitelj kao najvažniju vrijednost potvrdila su brojna istraživanja koja su se bavila strukturom i hijerarhijom vrijednosti, pri čemu se pokazalo da pojedinci, unatoč brojnim društvenim promjenama nastalima posljednjih tridesetak godina, još uvijek najvažnijima percipiraju obitelj i ljubav (Raboteg-Šarić, Pećnik i Josipović, 2003.; Janković, Berc i Blažeka, 2004.; Mrnjaus, 2008.). Istraživanja na adolescentnoj populaciji pokazala su da pri rangiranju vrednota mladi najvažnijima smatraju zdravlje, prijateljstvo, brak i djecu, dok je među vrijednosnim orijentacijama najistaknutija ona samoaktualizirajuća koju čine vrijednosti poput ljubavi, obitelji i prijateljstva (Franc, Šakić i Ivičić, 2002.; Vlah, Lončarić i Tatalović Vorkapić, 2011.).

Promatrajući i istražujući obitelj u kontekstu formiranja vrijednosnoga sustava pojedinca, istraživanja su ukazala na važnost obitelji kao ključnoga čimbenika u tom procesu. Primjerice, istraživanja su pokazala da je kvaliteta obiteljskih interakcija na relaciji roditelj-dijete važna odrednica usvajanja vrijednosti unutar obitelji, pri čemu pozitivni obrasci roditeljskoga ponašanja facilitiraju usvajanje i internalizaciju vrijednosti kod djece (Schonplug, 2001.). Usvajanje vrijednosti putem socijalizacije započinje u ranom djetinjstvu, a ključno razdoblje njihova strukturiranja u vrijednosni sustav jest adolescencija. Većina je autora suglasna da tako internaliziran vrijednosni sustav ostaje stabilan tijekom života (Rokeach i Ball-Rokeach, 1989.; Inglehart, 1990.).

Iako su istraživanjima vrijednosnih prioriteta ustanovljene neke dobne, odnosno generacijske razlike, na razini obitelji uočene su sličnosti u vrijednosnim prioritetima djece i njihovih roditelja (Ferić, 2009.). Neka su istraživanja pružila dokaze o prijenosu vrijednosti u obitelji (Youniss i Smollar, 1985.; Gecas i Seff, 1990.; Rohan i Zanna, 
1996.; Knafo i Schwartz, 2001.; Sabatier i Lannegrand-Willems, 2005.). Sličnost u sustavima vrijednosti roditelja i njihovih potomaka moguće je objasniti dvoprocesnim modelom (Goodnow, 1992.), prema kojem se unutarobiteljski prijenos sustava vrijednosti odvija u dva koraka. Prvi se odnosi na točno percipiranje i razumijevanje roditeljevih uvjerenja, a drugi na (ne)prihvaćanje percipiranoga roditeljskog sustava vrijednosti. Percipiranje i razumijevanje roditeljevih uvjerenja pod utjecajem su brojnih čimbenika, među kojima se posebno ističu komunikacijski, poput eksplicitnosti, jasnoće i sadržaja roditeljevih poruka, te međuroditeljska kongruentnost po pitanju vrijednosti, kao i usklađenost poruka kojima roditelji komuniciraju vlastiti sustav vrijednosti djetetu, sukladno njegovoj kognitivnoj zrelosti. S druge strane, (ne)prihvaćanje roditeljevih uvjerenja i vrijednosti posredovano je motivacijskim i afektivnim čimbenicima (Okagaki i Bevis, 1999.).

Ranija istraživanja povezanosti vrijednosnih sustava majki i njihovih adolescentnih kćeri nisu dala jednoznačne rezultate. Neka istraživanja, naime, nisu potvrdila povezanost u osnovnim životnim vrijednostima (Josefowicz i sur., 1994.), dok su neka istraživanja ukazala na kongruentnost u sustavu individualističkih (Sabatier i Lannegrand-Willems, 2005.) i kolektivističkih vrijednosti (Knafo i Schwartz, 2001.; Sabatier i Lannegrand-Willems, 2005.). Istraživanja o unutarobiteljskoj transmisiji vrijednosti temeljenih na Swartzovom modelu su ukazala na niske, ali značajne korelacije na svim domenama vrijednosti (Gronhoj i Thoegersen, 2010.).

\subsection{Stavovi prema braku}

Stavovi se formiraju na temelju neposrednoga iskustva pojedinca, te posredno, socijalnim učenjem u kojem kultura i obitelj oblikuju pojedinčeve stavove, a mijenjaju se uslijed socijalno-ekonomskih čimbenika, te izlaganja novim događajima i iskustvima (Bohner i Wanke, 2002.). Istraživanja su pokazala da su stavovi ključne proksimalne odrednice ponašanja vezanih uz obitelj, roditeljstvo, brak i razvod (Axinn i Thornton, 1992.; 1993.). Naime, duboko ukorijenjeni pozitivni stavovi prema braku utječu na ponašanje u prisnim odnosima i intimnim vezama budući da pojedinci s takvim stavovima streme izbjegavanju konflikata i neslaganja na partnerskoj relaciji, te održavanju kvalitete odnosa. S druge strane, stavovi su važni za odanost u partnerskim odnosima i predanost vezi na način da se teži održavanju odnosa i kada u njemu partner(i) ne doživljavaju zadovoljstvo.

Stavovi prema prisnim odnosima, braku i roditeljstvu stječu se socijalizacijom, pri čemu je iskustvo bračnoga odnosa vlastitih roditelja značajan čimbenik. Načini suočavanja i stilovi rješavanja bračnih konflikata roditelja, osim što utječu na njihov bračni odnos, posredno utječu i na percepciju bračnih odnosa od strane djeteta (Kapinus, 2005.). Tasker i Richards (1994.) su utvrdili da je količina roditeljskih bračnih konflikata povezana s načinom na koji njihova odrasla djeca stupaju u brak, zatim s vremenom ulaska u seksualne aktivnosti, te s negativnim osjećajima prema povezivanju i obvezivanju u intimnim odnosima. I druga istraživanja sugeriraju da postoji povezanost između roditeljskih bračnih konflikata i stavova njihove djece mlađe odrasle dobi prema braku (Amato, 1988.; Amato i DeBoer, 2001.; Moats, 
2004.). Pored toga, adolescenti iz razvedenih obitelji imaju pozitivniji stav prema razvodu braka u odnosu na one iz cjelovitih obitelji (Greenberg i Nay, 1982.; Amato i Booth, 1991.; Moats, 2004.). Pojedinci razvedenih roditelja izvještavaju o nižim očekivanjima uspjeha vlastite romantične veze u odnosu na pojedince iz cjelovitih obitelji (Riggio i Weiser, 2008.), vjerojatno stoga što usvajaju disfunkcionalne obrasce međupartnerskoga odnosa roditelja te ih internaliziraju u vlastite intimne odnose.

Prema teoriji međugeneracijskoga prijenosa razvoda, stavovi prema braku i bračni stilovi prenose se s roditelja na djecu, za što je odgovoran psihološki mehanizam koji se odnosi na razvoj kognicija vezanih uz interpersonalne odnose budući da roditeljski međuodnosi posredno i neposredno utječu na formiranje kognitivnih reprezentacija interpersonalnih odnosa kod pojedinca (Amato i DeBoer, 2001.; Herzog i Cooney, 2002.; Riggio i Weiser, 2008.). Primjerice, istraživanje Kapinusa (2004.) pokazalo je da stavovi roditelja prema razvodu braka imaju najveći utjecaj na stavove djeteta tijekom kasnih tinejdžerskih godina, te da stavovi majki o predbračnim seksualnim odnosima, kohabitaciji, braku i razvodu značajno utječu na stavove djece o istim pitanjima (Axin i Thornton, 1996.). U tom kontekstu, zanimljivim se činilo istražiti postoji li sličnost u stavu prema razvodu braka na unutarobiteljskoj razini, između majki i njihovih kćeri starije adolescentne i postadolescentne dobi.

\section{Ciljevi i hipoteze istraživanja}

S obzirom da vrijednosti predstavljaju standarde pomoću kojih se vrednuju vlastite aktivnosti i ponašanja drugih (Brown, 1996.), te da na kognitivnoj razini predstavljaju osnovne ljudske potrebe (Rohan i Zanna, 2001.), moguće ih je razmatrati i kao uzroke stavova, odnosno posredno i ponašanja pojedinca (Penington, 1997.). Stoga je jedan od ciljeva ovoga istraživanja bio ispitati determiniraju li životne vrijednosti, u kontekstu Brownove holističke teorije izbora životnih uloga temeljenih na vrijednostima (Brown, 1996.), stavove prema razvodu braka.

Promatrajući obitelj kao ključan čimbenik u formiranju vrijednosnoga sustava pojedinca koji se uglavnom formira do razdoblja adolescencije, a uzimajući u obzir liberalizaciju društva, što doprinosi mijenjanju vrijednosnih sustava na globalnoj i individualnoj razini, u ovom se istraživanju željelo provjeriti postoje li generacijske razlike u vrijednosnim prioritetima između majki i kćeri. Nadalje, s obzirom da se brak tradicionalno poima temeljem obitelji, istraživanjem se željelo provjeriti postoje li, s jedne strane, generacijske razlike u stavovima prema razvodu braka, te s druge strane, postoji li unutar obitelji (između majki i njihovih kćeri starije adolescentne i postadolescentne dobi) sličnost u stavovima prema razvodu braka. Kako bi se ostvarili navedeni ciljevi, u istraživanje se krenulo od sljedećih hipoteza:

1. Životne vrijednosti su značajne odrednice stavova prema razvodu braka;

2. U vrijednosnim prioritetima i stavovima prema razvodu braka postoje značajne međugeneracijske razlike;

3. Na unutarobiteljskoj razini postoji značajna povezanost u stavovima prema razvodu braka. 


\section{Metoda}

\subsection{Sudionici i postupak istraživanja}

Istraživanje je provedeno na prigodnom uzorku od 153 para majki i njihovih kćeri starije adolescentne i postadolescentne dobi (N=306) s područja Splitsko-dalmatinske županije ${ }^{1}$. Raspon dobi u skupini majki bio je od 34 do 63 godine uz prosječnu dob $M=47.75$ ( $s d=5.42$ ). S obzirom na radni status, $65 \%$ ih je zaposleno, $27 \%$ nezaposleno, a 8\% u mirovini. Najviše je majki sa završenom srednjom školom (66\%), $13 \%$ ih je sa završenom osnovnom školom, dok je $21 \%$ majki s višim i visokim obrazovanjem. Kada se ovi podaci o obrazovnom statusu usporede s podacima Državnoga zavoda za statistiku RH (2009.), može se uočiti da je obrazovna struktura sudionica ovoga istraživanja nešto povoljnija. Naime, prema dostupnim podacima iz popisa stanovništva RH iz 2001. godine, među ženama u rasponu od 35 do 64 godine (što odgovara rasponu dobi u uzorku istraživanja) 14,5\% je više i visokoobrazovanih, 40,5\% ima srednjoškolsko, a 44,9\% osnovnoškolsko obrazovanje (Žene i muškarci u Hrvatskoj, 2009.). U skupini kćeri, sve su studentice Sveučilišta u Splitu, dobnoga raspona od 18 do 27 godina $(M=20,9$; $s d=1,81)$. Sudjelovanje u istraživanju je bilo dobrovoljno i anonimno, a sudionicama su podijeljeni unaprijed šifrirani upitnici kako bi se u obradi rezultata mogli upariti rezultati majki i kćeri. Skupina kćeri popunjavala je upitnike u okviru nastave na fakultetima, a majke su ispunjavale upitnike kod kuće. Od ukupnoga broja podijeljenih upitnika (N=360), u konačnici je vraćeno i valjano popunjeno 306 upitnika.

\subsection{Instrumenti}

Inventar životnih vrijednosti (Life Values Inventory, Crace i Brown, 1996.) u izvorniku se sastoji od 42 čestice, a namijenjen je ispitivanju 14 životnih vrijednosti. U ovom istraživanju primijenjena je skraćena verzija upitnika koja se sastoji od 21 čestice i kojom se mjeri sedam životnih vrijednosti (pripadanje, briga za druge, intimnost, odgovornost, duhovnost, odanost grupi/obitelji, intima). Vrijednosti odanosti obitelji, pripadanja i brige za druge odnose na važnost poštovanja obiteljskih stečevina, ispunjavanja očekivanja obitelji i drugih bližnjih, osjećaja uključenosti i prihvaćenosti, te važnost dobrobiti drugih osoba. Intrapersonalne vrijednosti odnose se na intimu, neovisnost i duhovnost, pri čemu se intima odnosi na vrijeme posvećeno vlastitim potrebama, a neovisnost na važnost koju pojedinac pridaje samostalnom donošenju odluka i stvaranju vlastitih izbora, neovisno o utjecajima drugih. Duhovnost je definirana kao važnost koju pojedinac pridaje duhovnim,

1 Budući da u socijalizaciji vrijednosnoga sustava i stavova postoji cijeli niz osobnih i relacijskih čimbenika vrijednih istraživanja, fokus ovoga rada bio je usmjeren isključivo na relaciju majka - kći. Stoga bi u sljedećim istraživanjima valjalo uključiti ostale obiteljske podsustave (primjerice otac - kći, otac - sin, majka - sin), tim više što su takva istraživanja rijetka čak i u međunarodnim okvirima. 
odnosno religijskim vjerovanjima, s uvjerenjem da je dio nečega mnogo većega od sebe samoga. Odgovornost se odnosi na važnost povjerenja i pouzdanosti koje pojedinac iskazuje prema sebi i prema drugima (Almeida i Rebelo Pinto, 2004.), te se u tom smislu odgovornost može razmatrati kao intrapersonalna i interpersonalna značajka. Zadatak sudionika je da za svaku česticu procijeni koliko često je njegovo ponašanje određeno navedenim osobinama. Uz svaku česticu ponuđena je skala procjene od pet stupnjeva gdje 1 znači vrlo rijetko određuje moje ponašanje, a 5 znači gotovo uvijek određuje moje ponašanje. Eksploratornom faktorskom analizom metodom glavnih komponenata uz varimax rotaciju ekstrahirano je pet faktora, čije su vrijednosti karakterističnih korjenova prikazane na slici 1., a faktorska struktura i psihometrijske značajke subskala prikazane su u tablici 1.

Slika 1.

Broj karakterističnih korijena izlučenih faktora

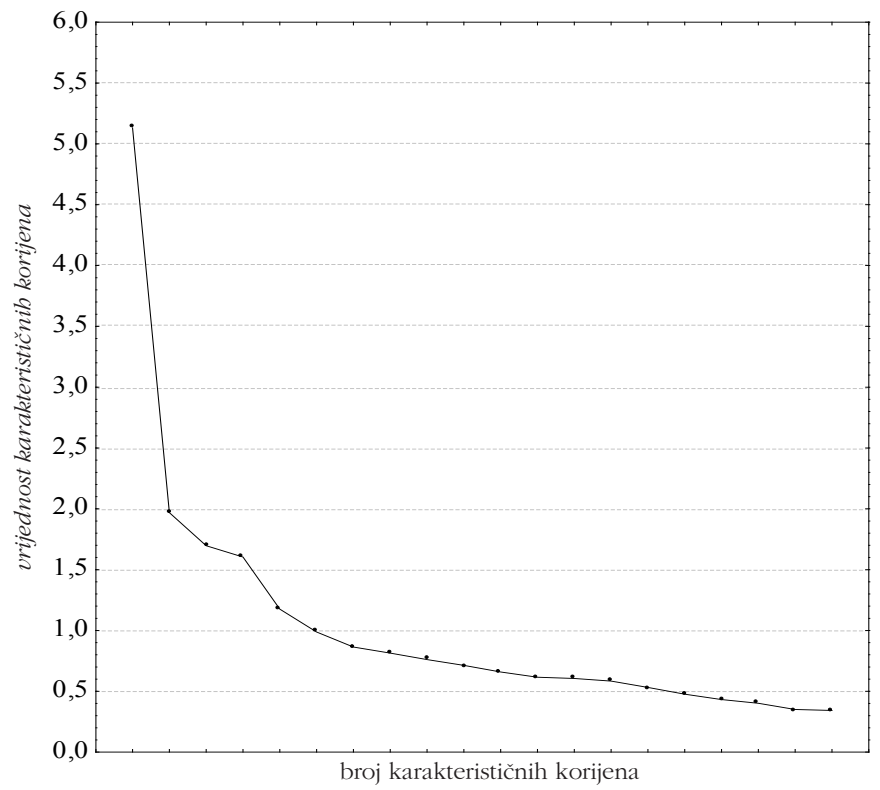

Tablica 1.

Faktorska struktura upitnika te psihometrijske značajke subskala Inventara životnih vrijednosti

\begin{tabular}{|l|c|c|c|c|c|}
\hline & F1 & F2 & F3 & F4 & F5 \\
\hline Biti neovisan. & .75 & & & & \\
\hline Biti pouzdan. & .56 & & & & \\
\hline Davanje vlastitog mišljenja. & .66 & & & & \\
\hline Biti osoba od povjerenja. & .45 & & & & \\
\hline Ispunjavanje vlastitih obveza. & .30 & & & & \\
\hline Imati vremena za sebe. & & .69 & & & \\
\hline
\end{tabular}




\begin{tabular}{|l|c|c|c|c|c|}
\hline & F1 & F2 & F3 & F4 & F5 \\
\hline Imati vremena za razmišljanje u tišini. & & .78 & & & \\
\hline Organiziranje vlastitog vremena. & & .59 & & & \\
\hline Imati svoje posebno mjesto za osamu. & & .78 & & & \\
\hline Vjerovanje u višu silu. & & & .76 & & \\
\hline Poštivanje obiteljskih i društvenih običaja. & & & .49 & & \\
\hline Vjerovanje da postoji nešto veće od nas samih. & & & .70 & & \\
\hline Živjeti u skladu sa svojim duhovnim uvjerenjima. & & & .64 & & \\
\hline Biti omiljen u društvu. & & & & .72 & \\
\hline Prihvaćenost vlastitog položaja u obitelji i društvu. & & & & .64 & \\
\hline Prihvaćenost od drugih. & & & & .78 & \\
\hline Biti osjetljiv za potrebe drugih. & & & & & .37 \\
\hline Pomaganje drugima. & & & & & .39 \\
\hline Pripadati nekome/nečemu. & & & & & .62 \\
\hline Zabrinutost za prava drugih. & & & & & .74 \\
\hline Donositi odluke uvažavajući potrebe drugih. & & & & & .60 \\
\hline \multicolumn{1}{|r|}{ obješnjenja varijanca } & $12 \%$ & $11 \%$ & $12 \%$ & $9 \%$ & $10 \%$ \\
\hline Cronbach $\alpha^{2}$ & .64 & .75 & .68 & .72 & .66 \\
\hline r mecu česticama & 21.07 & 13.89 & 16.18 & 10.47 & 19.82 \\
$(2.53)$ & $(3.23)$ & .27 & .35 & .46 & .29 \\
\hline
\end{tabular}

Iz tablice 1. vidljivo je da je faktorska struktura drugačija u odnosu na izvornik. S obzirom na sadržaj čestica i koeficijente pouzdanosti, formirano je pet subskala kojima se mjeri pet vrijednosti, te su u skladu s tim formirani rezultati po subskalama (F1 - neovisnost i odgovornost, F2 - intima, F3 - duhovnost, F4 - pripadanje, F5 - briga za druge).

Skala stavova prema razvodu braka (Kinnard i Gerrard, 1986.) sastoji se od 12 čestica kojima sudionici iskazuju pozitivne i negativne stavove prema razvodu braka. Skala obuhvaća niz izjava koje se odnose na različite vidove razvoda braka. Za svaku je česticu ponuđena skala Likertovoga tipa od pet stupnjeva na kojoj sudionici procjenjuju koliko se slažu sa svakom izjavom. Slično kao i u ranijim istraživanjima (Kinnard i Gerrard, 1986., Moats, 2004.), sve su čestice pokazale zadovoljavajuća zasićenja na jednom faktoru, izuzev jedne koja je izostavljana iz daljnje analize. Faktorska zasićenja i druge značajke skale prikazane su u tablici 2. Nakon obrnutoga bodovanja ukupni rezultat je formiran kao linearna kombinacija procjena na svim česticama, a veći rezultat ukazuje na pozitivniji stav prema razvodu braka.

2 Dobiveni koeficijenti pouzdanosti su zadovoljavajući s obzirom na mali broj čestica pojedinih subskala, a slični su dobiveni i u ranijim istraživanjima (Almeida i Rebelo Pinto, 2004.) 
Tablica 2.

Faktorska struktura upitnika te psihometrijske značajke Skale stavova prema razvodu braka

\begin{tabular}{|l|c|}
\hline & F1 \\
\hline $\begin{array}{l}\text { Ako su ljudi u braku nesretni, dužni su zbog sebe rastati se i pokušati poboljšati } \\
\text { svoj život. }\end{array}$ & .65 \\
\hline Ljudi ne bi trebali osjećati obavezu ostati u braku ako nisu zadovoljni. & .73 \\
\hline $\begin{array}{l}\text { U današnje vrijeme bračni zavjet "do kraja života" je samo formalnost. To } \\
\text { ustvari ne znači da ljudi trebaju ostati u lošem braku. }\end{array}$ & .66 \\
\hline $\begin{array}{l}\text { Činjenica da većina ljudi ne osjeća da mora ostati u lošem braku će koristiti i } \\
\text { društvu u cjelini. }\end{array}$ & .48 \\
\hline $\begin{array}{l}\text { Većina ljudi koja se rastavlja, pribjegava razvodu kao posljednjem rješenju } \\
\text { nakon što su pokušali sve da riješe probleme u braku. }\end{array}$ & .42 \\
\hline Kada se ljudi žene, morali bi ostati zajedno bez obzira što se dogodilo. & .69 \\
\hline Bračni zavjet "do kraja života" je svetinja i ne bi se trebao olako shvaćati. & .55 \\
\hline Dugoročno, veliki broj razvoda brakova će nauditi hrvatskom društvu u cjelini. & .50 \\
\hline $\begin{array}{l}\text { Mnogi ljudi koji su se razveli su preslabi i ne mogu se žrtvovati za dobro } \\
\text { obitelji. }\end{array}$ & .55 \\
\hline $\begin{array}{l}\text { Čak i ako su ljudi nezadovoljni u braku trebali bi ostati zajedno i pokušati } \\
\text { poboljšati brak. }\end{array}$ & .69 \\
\hline Većina djece rastavljenih roditelja ima negativne posljedice do kraja života. & .43 \\
\hline \multicolumn{1}{|c|}{ objašnjena varijanca } & $35 \%$ \\
\hline \multicolumn{1}{|c|}{ Cronbach $\alpha$} & .81 \\
\hline & $\begin{array}{l}.82 .09 \\
(5.60)\end{array}$ \\
\hline
\end{tabular}

\section{Rezultati}

Kako bi se ispitale generacijske razlike u stavovima prema razvodu braka i životnim vrijednostima, provedene su analize s ciljem utvrđivanja razlika između skupina majki i kćeri u zavisnim varijablama. Rezultati tih analiza prikazani su u tablicama 3. i 4.

Tablica 3.

Prosječne vrijednosti i standardne devijacije, te rezultati usporedbi skupina s obzirom na stav prema razvodu braka

\begin{tabular}{|c|c|c|c|c|c|}
\hline & \multicolumn{2}{|c|}{ majke } & \multicolumn{2}{c|}{ kćeri } & \multirow{2}{*}{} \\
\cline { 2 - 5 } & M & sd & M & sd & t (df=147) \\
\hline stav prema razvodu braka & 27.34 & 5.50 & 28.84 & 5.50 & $-2.39^{*}$ \\
\hline
\end{tabular}

${ }^{*} \mathrm{p}<.05$ 
Tablica 4.

Prosječne vrijednosti i standardne devijacije, te rezultati usporedbi skupina s obzirom na životne vrijednosti

\begin{tabular}{|c|c|c|c|c|c|c|c|c|c|c|c|c|}
\hline \multicolumn{2}{|c|}{$\begin{array}{l}\text { neovisnost } \mathrm{i} \\
\text { odgovornost }\end{array}$} & \multicolumn{2}{|c|}{ intima } & \multicolumn{2}{|c|}{ duhovnost } & \multicolumn{2}{|c|}{ pripadanje } & \multicolumn{2}{|c|}{$\begin{array}{l}\text { briga za } \\
\text { druge }\end{array}$} & \multicolumn{3}{|c|}{ ANOVA } \\
\hline $\mathrm{m}$ & $\mathrm{k}$ & $\mathrm{m}$ & $\mathrm{k}$ & $\mathrm{m}$ & $\mathrm{k}$ & $\mathrm{m}$ & $\mathrm{k}$ & $\mathrm{m}$ & $\mathrm{k}$ & $\begin{array}{l}\text { skupina } \\
\mathrm{F}_{1,304}\end{array}$ & $\begin{array}{l}\text { vrijednosti } \\
\mathrm{F}_{1,304}\end{array}$ & $\begin{array}{c}\text { interakcija } \\
\mathrm{F}_{4,1216}\end{array}$ \\
\hline $\begin{array}{l}4.18 \\
(.56)\end{array}$ & $\begin{array}{l}4.25 \\
(.44)\end{array}$ & $\begin{array}{l}3.20 \\
(.81)\end{array}$ & $\begin{array}{l}3.75 \\
(.70)\end{array}$ & $\begin{array}{l}4.11 \\
(.74)\end{array}$ & $\begin{array}{l}3.98 \\
(.71)\end{array}$ & $\begin{array}{l}3.40 \\
(.82)\end{array}$ & $\begin{array}{l}3.58 \\
(.74)\end{array}$ & $\begin{array}{l}3.98 \\
(.57)\end{array}$ & $\begin{array}{l}3.95 \\
(.54)\end{array}$ & $6.70^{*}$ & $111.0^{* * *}$ & $17.1^{* * *}$ \\
\hline
\end{tabular}

${ }^{*} \mathrm{p}<.05 ;{ }^{* *} \mathrm{p}<.01$

Iz tablice 3. vidljivo je da postoje značajne razlike u skupinama sudionica s obzirom na stav prema razvodu braka, pri čemu pozitivniji stav iskazuje mlađa skupina. Nadalje, utvrđene su neke razlike u procjeni važnosti pojedinih životnih vrijednosti (tablica 4.). Kao najvažniju vrijednost obje skupine sudionica su procijenile neovisnost i odgovornost, a kao najmanje važnu majke procjenjuju intimu, a kćeri pripadanje. Naknadna analiza rezultata (Scheffe test) je pokazala da se dobivena značajna razlika između dviju skupina sudionica može pripisati razlici u intimi $(\mathrm{p}<.05)$ koju značajno važnijom procjenjuje skupina kćeri nego skupina majki. Naknadna analiza je pokazala da u ostalim vrijednostima nema značajnih razlika između dviju skupina sudionica.

Kako bi se ispitala sličnost vrijednosnih prioriteta i stavova prema razvodu braka na unutarobiteljskoj razini, izračunati su t-testovi za zavisne uzorke (parovi majki i kćeri) za navedene varijable koji su prikazani u tablici 5.

Tablica 5.

Prosječne vrijednosti, rezultati t-testova te koeficijenti korelacija između parova majki i kćeri za životne vrijednosti i stavove prema razvodu braka

\begin{tabular}{|c|c|c|c|c|}
\hline varijable & $\begin{array}{c}\text { M (sd) } \\
\text { (majke) }\end{array}$ & $\begin{array}{l}\text { M (sd) } \\
\text { (kćeri) }\end{array}$ & $t(d f=147)$ & $r$ \\
\hline stav prema razvodu braka & $27.34(5.53)$ & $28.84(5.50)$ & $-3.36^{* * *}$ & $.49^{* * *}$ \\
\hline \multicolumn{5}{|l|}{ vrijednosti } \\
\hline neovisnost i odgovornost & $4.18(.57)$ & $4.26(.43)$ & -1.67 & $.26^{* *}$ \\
\hline intima & $3.19(.81)$ & $3.75(.60)$ & $-7.60^{* * *}$ & $.33^{\text {*** }}$ \\
\hline duhovnost & $4.11(.74)$ & $3.96(.72)$ & 1.93 & $.41^{* * *}$ \\
\hline pripadanje & $3.39(.84)$ & $3.56(.75)$ & $-2.50^{*}$ & $.43^{* *}$ \\
\hline briga za druge & $3.98(.84)$ & $3.96(.54)$ & .27 & $.30^{* * *}$ \\
\hline
\end{tabular}

${ }^{* *} \mathrm{p}<.01 ; * \mathrm{p}<.05$ 
Iz tablice 5. je vidljivo da na unutarobiteljskoj razini postoje značajne razlike u stavu prema razvodu braka te nekim vrijednosnim prioritetima između majki i kćeri. Kćeri u odnosu na svoje majke imaju pozitivniji stav prema razvodu braka. S obzirom na životne vrijednosti, značajne su razlike dobivene u vrijednostima intime i pripadanja, pri čemu su obje vrijednosti značajno važnijima procijenile kćeri u odnosu na svoje majke.

Izračunati koeficijenti korelacija pokazuju da postoji značajna povezanost između majki i njihovih kćeri u svim zavisnim varijablama, što ide u prilog unutarobiteljskom prijenosu vrijednosti i stavova.

Kako bi se istražio pojedinačni doprinos životnih vrijednosti objašnjenju stava prema razvodu braka, izračunate su standardne regresijske analize sa stavom prema razvodu braka kao kriterijem, posebno u skupini majki i posebno u skupini kćeri. U tablici 6. prikazani su rezultati tih standardnih regresijskih analiza.

Tablica 6.

Rezultati standardnih regresijskih analiza sa stavom prema razvodu braka kao kriterijem

\begin{tabular}{|c|c|c|}
\hline & majke & kćeri \\
\hline & $\beta$ & $\beta$ \\
\hline dob & -.09 & - \\
\hline zadovoljstvo životom & .06 & -.07 \\
\hline zadovoljstvo brakom & -.09 & - \\
\hline neovisnost i odgovornost & .12 & $.18^{*}$ \\
\hline intima & -.05 & -.06 \\
\hline duhovnost & $-.44^{* * *}$ & $-.31 * *$ \\
\hline pripadanje & .03 & -.03 \\
\hline briga za druge & -.08 & .03 \\
\hline$F(d f)$ & $4.62 * *(8,144)$ & $2.64 *(6,146)$ \\
\hline $\mathrm{R}\left(\mathrm{R}^{2}\right)$ & $.45(.20)$ & $.31(.10)$ \\
\hline
\end{tabular}

${ }^{* *} \mathrm{p}<.01 ;{ }^{*} \mathrm{p}<.05$

Iz tablice 6. vidljivo je da se samo duhovnost kao životna vrijednost pokazala prediktivnom za stav prema razvodu braka u skupini majki, dok su se u skupini kćeri, pored duhovnosti, prediktivnima pokazale vrijednosti neovisnost i odgovornost. Za ostale vrijednosti nisu utvrđeni značajni regresijski koeficijenti. Bez obzira na relativno širok dobni raspon u skupini majki (34 - 63), dob se nije pokazala prediktivnom za stav prema razvodu braka. 


\section{Rasprava}

Jedan od problema ovoga istraživanja bio je usporediti vrijednosne prioritete u dvjema generacijskim skupinama. Budući da je ključno razdoblje strukturiranja i stabiliziranja vrijednosti u vrijednosni sustav razdoblje adolescencije, a imajući na umu sasvim različito društveno okruženje koje je prevladavalo u doba formiranja vrijednosnoga sustava majki i današnjih adolescenata i postadolescenata, opravdanim se činilo pretpostaviti postojanje razlika u vrijednosnim prioritetima između tih dviju skupina. Rezultati su pokazali da obje generacije najvažnijim vrijednostima koje determiniraju njihovo ponašanje procjenjuju neovisnost i odgovornost, dok je jedina značajna razlika utvrđena u vrednovanju intime koja se pokazala značajno prioritetnijom u mlađoj generacijskoj skupini.

S obzirom da neovisnost podrazumijeva važnost koju pojedinac pridaje samostalnom donošenju odluka i stvaranju vlastitih izbora neovisno o utjecajima drugih, ne iznenađuje što je u skupini starijih adolescentica i postadolescentica upravo ta vrijednost prioritetna, uzimajući u obzir razvojne zadatke tipične za ovu dobnu skupinu. Naime, stariji adolescenti i postadolescenti se nalaze na prijelazu u odraslu dob, a taj je prijelaz određen brojnim događajima kao što su završetak školovanja, zaposlenje i financijska neovisnost, te život odvojen od primarne obitelji, što uključuje brak i roditeljstvo (Schaie i Willis, 2001.). S druge strane, u istraživanje se krenulo od pretpostavke da će skupina majki u skladu s tradicionalnim poimanjem uloge žene prioritetnima procijeniti vrijednosti, poput brige za druge ili pripadanja. Rezultati su, pak, pokazali da skupina majki također prioritetnima procjenjuje neovisnost i odgovornost u determiniranju njihovoga ponašanja. Dobiveni rezultati idu u prilog poimanju neovisnosti i odgovornosti kao važnih vrijednosti suvremenoga društva, te se implicitno i eksplicitno pojavljuju u širem kontekstu od obiteljskog odgoja. Primjerice, i u odgojno-obrazovnom kontekstu razvijanje identiteta, individualnosti, poštivanje ljudskih sloboda i pluralizam, zagovaraju slobodu i neovisnost svakoga pojedinca (Nacionalni okvirni kurikulum, 2010.). Slično neovisnosti, i odgovornost se u suvremenom društvu ističe kao temeljna društvena, kulturna i odgojno-obrazovna vrijednost koja promiče odgovorno djelovanje i ponašanje s ciljem stvaranja smislenoga i savjesnoga odnosa između osobne slobode i društvene odgovornosti. Važnost odgovornosti u vrijednosnim prioritetima mladih potvrdila su i neka ranija istraživanja (Reić Ercegovac i Ljubetić, 2010.). U obiteljskom kontekstu, upravo je odgovornost gotovo najteža i najkompleksnija roditeljska zadaća. Naime, da bi dijete naučilo odgovorno se ponašati, potrebno mu je stvoriti takav kontekst za učenje u kojem će ono od najranije dobi moći slobodno činiti vlastite izbore, te naučiti snositi prirodne posljedice učinjenih izbora. S obzirom da je hrvatska obiteljska i obrazovna politika snažno usmjerena na cjeloviti osobni razvoj pojedinca, s jedne strane, i stvaranje društvenih vrijednosti, s druge strane, odgovornost, identitet i solidarnost predstavljaju ključne vrijednosti, kako na društveno-kulturnoj, tako i na odgojnoobrazovnoj razini.

Rezultati istraživanja su pokazali da se dvije generacijske skupine značajno razlikuju $\mathrm{u}$ vrednovanju intime kao intrapersonalne vrijednosti koja se odnosi na vrijeme posvećeno vlastitim potrebama, pri čemu se pokazalo da skupina kćeri značajno 
više od skupine majki vrednuje intimu. Dobiveni rezultati mogu se s jedne strane pripisati razvojnim obilježjima starijih adolescenata i postadolescenata, a s druge strane može se pretpostaviti da je značajno veće vrednovanje intime u mlađoj skupini dijelom uzrokovano medijskim i društvenim poticanjem vrednovanja intime kao važne osobne vrijednosti.

Nadalje, istraživanjem se htjelo provjeriti postoje li generacijske razlike u stavu prema razvodu braka. Rezultati su pokazali da skupina kćeri ima značajno pozitivniji stav prema razvodu braka u odnosu na skupinu majki. Ovakav je rezultat i očekivan s obzirom na kontekstualne i strukturalne promjene na društvenoj i obiteljskoj razini koje su se odrazile na porast stope razvoda braka, na što upućuju i podaci iz Statističkoga ljetopisa Republike Hrvatske (2010.). Dobiveni rezultati u skladu su s nekim ranijim istraživanjima u kojima se pokazalo da mlađe generacije imaju pozitivnije stavove prema razvodu braka te drugim alternativnim načinima organiziranja života (Martin, 2000.). Naime, načini organiziranja života u suvremenom društvu postaju sve različitiji, pa brak više ne predstavlja jedini način organiziranja obiteljskoga života.

Polazeći od pretpostavke da na unutarobiteljskoj razini postoji kongruentnost u Životnim vrijednostima i stavovima, istraživanjem se htjela utvrditi povezanost između majki i njihovih kćeri s obzirom na navedene životne vrijednosti te posebno stav prema razvodu braka. Rezultati su pokazali da postoje značajne korelacije, kako u stavu prema razvodu braka, tako i u svim vrijednostima na unutarobiteljskoj razini. Dobiveni rezultati u skladu su s rezultatima nekih ranijih istraživanja (Axinn i Thornton, 1996.; Abito i Weng, 2005.), a mogu se objasniti modelom unutarobiteljske transmisije stavova i vrijednosnih prioriteta. Unatoč generacijskim razlikama u vrijednosnim prioritetima i stavovima koji su posljedica različitih društvenih čimbenika (vršnjačkih, medijskih i ekoloških), očito je da u formiranju stavova i vrijednosnoga sustava pojedinca značajnu ulogu ima obiteljski kontekst. Prijenos roditeljskih socijalnih kognicija na djecu posredovan je kvalitetom interakcija na relaciji roditeljdijete, pri čemu pozitivni obrasci roditeljskoga ponašanja facilitiraju usvajanje i internalizaciju vrijednosti kod djece (Schonplug, 2001.).

Razmatrajući vrijednosti kao odrednice stavova i ponašanja pojedinaca, u istraživanje se krenulo od pretpostavke da će životne vrijednosti u značajnoj mjeri doprinijeti objašnjenju stava prema razvodu braka. S tim ciljem provedena je regresijska analiza sa stavom prema razvodu braka kao kriterijem te životnim vrijednostima kao prediktorima, posebno u dvije skupine sudionica. Rezultati tih analiza ukazali su na važnost duhovnosti u predikciji stava prema razvodu braka, dok se ostale vrijednosti u skupini majki nisu pokazale relevantnima. S obzirom da se duhovnost kao životna vrijednost temelji na religijskim uvjerenjima koja brak smatraju temeljnim polazištem obitelji, ne iznenađuje da sudionice koje duhovnost percipiraju važnijom u vlastitom sustavu vrijednosti imaju negativniji stav prema razvodu braka. S druge strane, niže vrednovanje duhovnosti kao životne vrijednosti može se povezati s pozitivnijim stavom prema razvodu braka. Nadalje, u skupini kćeri, pored duhovnosti prediktivnom su se pokazale vrijednosti neovisnost i odgovornost na način da sudionice koje veću važnost pridaju tim vrijednostima imaju pozitivniji stav prema razvodu braka. U 
objašnjenju rezultata treba napomenuti da sve vrijednosti zajedno objašnjavaju relativno malen dio varijance stava prema razvodu braka te bi u narednim istraživanjima valjalo ispitati prediktivnu vrijednost i nekih drugih interpersonalnih i intrapersonalnih varijabli koje mogu doprinijeti boljem razumijevanju stavova prema braku i razvodu braka.

\section{Zaključak}

Provedenim se istraživanjem htjelo proširiti spoznaje o nekim odrednicama stavova prema razvodu braka što se u aktualnom društvenom trenutku kojega obilježava sve veća stopa razvedenih brakova čini važnim i vrijednim znanstvenoga interesa. Štoviše, relativno je malo istraživanja koja se bave ispitivanjem odrednica stavova prema braku i razvodu braka, a značajno je više radova posvećeno propitivanjem posljedica razvoda braka, kako na individualnoj razini, u smislu psihosocijalnoga razvoja djece, tako i na široj razini, u smislu promjena strukture obitelji i društva u cjelini. Odrednice stavova prema razvodu braka relevantne su za percepciju i praksu obiteljskih odnosa, budući da je poznato da su stavovi temeljne odrednice stvarnoga ponašanja pojedinca. Stoga je namjera ovoga rada bila prikazati neke odrednice stavova prema razvodu braka s obzirom na unutarobiteljski i međugeneracijski prijenos stavova i vrijednosnih prioriteta.

Polazna hipoteza prema kojoj se očekivalo da su životne vrijednosti značajni prediktori stavova prema razvodu braka djelomično je potvrđena, budući da se u obje skupine sudionica jedino duhovnost kao životna vrijednost koja odražava pojedinčevu predanost duhovnim i religijskim uvjerenjima pokazala prediktivnom za stavove prema razvodu braka.

Pretpostavka o međugeneracijskim razlikama u vrijednosnim prioritetima i stavovima prema razvodu braka djelomično je potvrđena budući da su razlike potvrđene za stavove prema razvodu braka, dok su u životnim vrijednostima sudionice obje generacijske skupine iskazale slične vrijednosne prioritete.

S obzirom na treću hipotezu, na unutarobiteljskoj razini je utvrđena značajna povezanost i u vrijednosnim prioritetima i u stavovima prema razvodu braka, što ide u prilog modelima obiteljske transmisije vrijednosti i posredno stavova s obzirom na njihov strukturalno-sukcesivni odnos (Pennington,1997.).

Pri izvođenju navedenih zaključaka potrebno je osvrnuti se na ograničenja provedenoga istraživanja. Naime, osim prigodnosti uzorka, istraživanjem su obuhvaćene samo studentice i njihove majke, što donekle sužava mogućnost generalizacije dobivenih rezultata. Kako bi se osigurala reprezentativnost rezultata, u narednim bi istraživanjima valjalo uključiti heterogeniju skupinu adolescenata i adolescentica s obzirom na stupanj obrazovanja i radni status, te uključiti širi dijapazon osobnih i odnosnih varijabli (kvalitetu interakcije s majkom i ocem) u objašnjenju stavova prema braku i razvodu braka. 


\section{Literatura}

1. Abito, J. and Weng, H. (2005). Intergenerational Transmission of Family Formation Attitudes in Singapore: The Role of the Father. 15. lipnja 2011. (http:// www.childrensociety.org.sg/downloadpapers/papersfiles/Abito, \%20Jose $\% 20$ Miguel(Poster).pdf).

2. Almeida, L. and Rebelo Pinto, H. (2004). Life Value Inventory (LVI): Portuguese Adaptation Studies. 15. siječnja 2010. (http://www.contactpoint.ca/cjcd/v3-n1/ article4.pdf).

3. Amato, P. R. (1988). Parental Divorce and Attitudes toward Marriage and Family Life. Journal of Marriage and the Family, 50: 453-461.

4. Amato, P. R. and Booth, A. (1991). Consequences of parental divorce and marital unhappiness for adult well-being. Social Forces, 69: 895-914.

5. Amato, P. R. and DeBoer, D. D. (2001). The transmissions of marital instability across generations: Relationship skills or commitment to marriage? Journal of Marriage and the Family, 63: 1038-1051.

6. Axinn, W. G. and Thornton, A. (1993). Mothers, Children, and Cohabitation: The Intergenerational Effects of Attitudes and Behavior. American Sociological Review, 8 (2): 233-246.

7. Axinn, W. G. and Thornton, A. (1996). The Influence of Parents Marital Dissolutions on childrens Attitudes Toward Family Formation. Demography, 33 (1): 66-81.

8. Axinn,W. G. and Thornton, A. (1992). The Relationship Between Cohabitation and Divorce: Selectivity or Causal Influence? Demography, 29 (3): 357-374.

9. Bohner, G. and Wänke, M. (2002). Attitudes and Attitude Change. Hove (UK): Psychology Press.

10. Brown, D. (1996). A holistic, values-based model of life role decision making and satisfaction, in: D. Brown (Ed.). Career Choice and Development (3rd ed.). San Francisco: Jossey-Bass.

11. Crace, R. and Brown, D. (1996). Life Values Inventory. Chapel Hill, NC: Life Values Resources.

12. Crkvenčić - Bojić, J. (Ur.) (2009). Žene i muškarci u Hrvatskoj 2009. Zagreb: Državni zavod za statistiku RH.

13. Ferić, I. (2009). Vrijednosti i vrijednosni sustavi: psibologijski pristup. Zagreb: Alinea.

14. Franc, R.; Šakić, V. i Ivičić, I. (2002). Vrednote i vrijednosne orijentacije adolescenata: hijerarhija i povezanost sa stavovima i ponašanjima. Društvena istraživanja, 11 (2-3): 215-238.

15. Gecas, V. and Seff, M. (1990). Families and Adolescents: A review of the 1980s. Journal of Marriage and the Family, 52: 941-958.

16. Goodnow, J. J. (1992). Parents' ideas, children's ideas: Correspondence and divergence, in: I. E. Sigel; A. V. McGillicuddy-DeLisi and J. J. Goodnow (Eds.). Parental belief systems: The psychological consequences for children. Hillsdale, New Yersey: Erlbaum.

17. Greenberg, E. and Nay, W. (1982). The intergenerational transmission of marital instability reconsiderd. Journal of Marriage and the Family, 44: 335-347. 
18. Gronhoj, A. and Thogersen, J. (2010). Like father, like Son? Intergenerational transmission of values, attitudes, and bahviours in the environmental domain. Poster presented at Sustainable innovation workshop. Denmark: Arhus.

19. Herzog, M. and Cooney, T. (2002). Parental divorce and perceptions of past interparental conflict. Journal of Divorce \& Remarriage, 36: 89-110.

20. Inglehart, R. (1990). Cultural Change in Advanced Industrial Societies. Princenton, New York: Princenton University Press.

21. Janković, J.; Berc, G. i Blažeka, S. (2004). Neke opće i obiteljske vrednote u selu i gradu. Sociologija sela, 42 (1/2): 91-111.

22. Josefowicz, D.; Barber, B.; Eccles, J.; Mollasis, C. (1994). Relations Between Maternal and Adolescent Values and Beliefs: Gender Differences and Imlications for Occupational Choice. Paper presented at the Biennial Meeting of the Societa for Research on Adolescence: San Diego, California.

23. Kapinus, C. (2004). The effect of parents`attitudes toward divorce on offspring `s attitudes: Gender and parental divorce as mediating factors. Journal of family issues, 25: 112-135.

24. Kapinus, C. (2005). The effect of parental marital quality on young adults' attitudes toward divorce. Sociological perspectives, 48 (3): 319-335.

25. Kinnaird, K. and Gerrard M. (1986). Attitudes about marriage, divorce, and premarital sexual activity as a function of parents' marital status. Journal of Marriage and the Family, 48: 757-765.

26. Knafo, A. and Schwartz, S. H. (2001). Value socialization in families of Israeliborn and Soviet-born adolescents in Israel. Journal of Cross-Cultural Psychology, 32 (2): 213-228.

27. Martin, P. (2000). Expressed attitudes of adolescents toward marriage and family life. Dissertation Abstracts International: Section B: The Sciences and Engineering, 60 (9): 49-65.

28. Moats, M. M. (2004). The Effects of Parental Marriage, Divorce and Conflict on College Students' Attitudes Toward Marriage and Divorce. Thesis. Department of Family Studies and Social Work. Miami Unioversity, Oxford, Ohio.

29. Mrnjaus, K. (2008). Pedagoška promišljanja o vrijednostima. Rijeka: Filozofski fakultet Sveučilišta u Rijeci.

30. Nikodem, K. (2010). Religija i obitelj. Utjecaj kršćanskog identiteta na percepciju odnosa roditelja i djece. Socijalna ekologija: časopis za ekološku misao i sociologijska istraživanja okoline, 19 (2): 173-194.

31. Puljiz, V. i Bouillet, D. (Ur.) (2003). Nacionalna obiteljska politika Republike Hrvatske. Zagreb: Državni zavod za zaštitu obitelji, materinstva i mladeži.

32. Nacionalni okvirni kurikulum (2010). (www.mzos.hr).

33. Okagaki, L. and Bevis, C. (1999). Transmission of Religious Values: Relations Between Parents' and Daughters' Beliefs. The Journal of Genetic Psychology, 160 (3): 303-318.

34. Ostroški, Lj. (Ur.) (2010). Statistički ljetopis Republike Hrvatske. Državni zavod za statistiku Republike Hrvatske.

35. Pennington, D. C. (1997). Osnove socijalne psihologije. Jastrebarsko: Naklada Slap. 
36. Raboteg-Šarić, Z.; Pećnik, N. i Josipović, V. (2003). Jednoroditeljske obitelji: osobni doživljaj i stavovi okoline. Zagreb: Državni zavod za zaštitu obitelji, materinstva i mladeži.

37. Reić Ercegovac, I. i Ljubetić, M. (2010). Školske i obiteljske vrijednosti iz perspektive studenata. Pregled - časopis za društvena pitanja, 2: 229-249.

38. Riggio, H. R. and Weiser, D. A. (2008). Attitudes toward marriage: Embeddedness and outcomes in personal relationships. Personal Relationships, 15: 123140.

39. Rohan, M. P. and Zanna, M. P. (1996). Value transmission in Families. The psychology of values. The Ontario symposium, 8: 253 -276.

40. Rokeach, M. and Ball - Rokeach, M. (1989). Stability and change in American value priorities, 1968-1981. American Psychologist, 44: 775-785.

41. Sabatier, C. and Lannegrand-Willems, L. (2005.). Transmission of Family Values and Attachment: A French Three-Generation Study. Applied Psychology: An International Review, 54 (3): 378-395.

42. Schaie, K. W. i Willis, S. L. (2001). Psibologija odrasle dobi i starenja. Jastrebarsko: Naklada Slap.

43. Schonpflug, U. (2001). Intergenerational transmission of values: The role of transmission belts. Journal of Cross-Cultural Psychology Special Issue: Perspectives on Cultural Transmission, 32: 174-185.

44. Šverko, B.; Babarović, T. i Šverko, I. (2007). Vrijednosti i uloge u odabiru karijere. Suvremena psibologija, 10 (2): 295-323.

45. Tasker, F. L. i Richards, M. P. (1994). Adolescents' attitudes toward marriage and marital prospects after parental divorce: A review. Journal of Adolescent Research, 9: 340-362.

46. Vlah, N.; Lončarić, D. i Tatalović Vorkapić, S. (2011). Struktura vrijednosnih orijentacija i hijerarhija vrednota učenika strukovnih škola. Društvena istraživanja, 20 (2): 479 - 493.

47. Youniss, J. and Smollar, J. (1985). Adolescent relations with mother, fathers, and friends. Chicago: University Chicago Press. 
Ina Reić Ercegovac

Faculty of Philosophy, Department of Pedagogy, University of Split, Croatia

e-mail: inareic@ffst.hr

Morana Koludrović

Faculty of Philosophy, Department of Pedagogy, University of Split, Croatia

e-mail:morana@ffst.hr

\title{
Life Values and Divorce - Inter-generation and Family Perspective
}

\begin{abstract}
The perception of family and marriage is changing in the Croatian society in the sense that the patriarchal model is being abandoned (Nikodem, 2010.). This is partly evident in the ever growing divorce rate. However, the research shows that family is still the greatest of life values both in Europe and in Croatia. It is still the most important factor in the formation of the value system of an individual. In the family value transfer model (Goodnow, 1992.), it is reasonably expected that priorities and attitudes regarding life values are very similar within one family. Still, this hypothesis has not been confirmed by some research (Josefowich et al., 1994.). Hence in our research we wished to examine whether there are generation related differences towards divorce on the one hand and family congruity on the other. Another goal of this research was to establish whether life values determine individual attitudes towards divorce.

306 respondents took part in the research (153 pairs of mothers and their late adolescent and post-adolescent daughters). A shorter version of Life Values Inventory was used (Crace and Brown, 1996.) as well as Attitudes Toward Divorce Scale (Kinnard and Gerard, 1986.).

The results show that daughters hold a much more positive attitude towards divorce than their mothers. They also value intimacy more than their mothers. Within the family there is a high level of agreement on value priorities and attitudes towards divorce. In both groups of respondents spirituality as a life value plays an important role in their attitude towards divorce, while other values are largely irrelevant.
\end{abstract}

Key words: life values, attitude towards divorce, generation differences, family connection. 